\title{
Impact of Watershed Interventions on Soil Physicochemical Properties in Kechi Micro-Watersheds of Kechi District, Dawuro Zone, Ethiopia
}

\author{
Gemechu Fufa Arfasa* Nigatu Abera Kebede Barena Adare Amamo \\ Wolaita Sodo University Dawuro Tarcha Campus, Department of Natural Resource Management, \\ P.O.Box.138 Wolaita, Ethiopia
}

\begin{abstract}
A watershed refers to any topographically delineated area that can collect water and is drained by river system $\mathrm{w}$ ith an outlet. The objective of this study is to evaluate the impact of watershed interventions on soil properties micro-watershed of Kechi distirict, Dawuro zone, SNNPR Ethiopia. In this study the researcher adopted a combination of both quantitative and qualitative methodologies. The necessary information was collected from both from primary and secondary sources. Soil samples were collected using 15-cm depth auger and 294.375 $\mathrm{cm} 3$ core sampler at a depth of $0-30 \mathrm{~cm}$. A total of 24 composite and core soil samples from Conserved and Non conserved watershed were collected. Soil samples were collected from upstream, midstream, and downstream part of the watershed to make representative for the whole watershed. Soil sample which was taken from representative area was analyzed by soil laboratory analysis. Watershed interventions have resulted in a statistically significantly higher mean value of total nitrogen, exchangeable $\mathrm{Na}+$ and $\mathrm{Mg} 2+$ at $\mathrm{p}<0.01$, and of soil organic carbon and organic matter at $\mathrm{p}<0.05$ in the watershed. The clay content, soil reaction, cation exchange capacity, and exchangeable $\mathrm{K}+$ showed non-significant, but higher mean values in conserved plots. Furthermore, the effects of conservation practices on soil properties were found more effective in cultivated land uses as compared to that of grazing land uses. This is because conservation treatments had significant effects on organic carbon, total nitrogen, exchangeable $\mathrm{Na}+$ and $\mathrm{Mg} 2+$ in cultivated land uses but only on exchangeable $\mathrm{Na}+$ in grazing land uses. The interaction effect of treatments and land uses did not reach a statistically significant result for any of the soil properties considered in this study. Watershed interventions have important implications for improving soil fertility in the kechi micro watershed. Therefore, proper guidance and follow-up, use of agro-forestry and grass strips, and maintenance are required for the watershed's sustainability and good soil
\end{abstract}

Keywords: - Analysis of variance, Kechi micro watersheds, Socio-Economic Status, Soil properties

DOI: $10.7176 / \mathrm{JRDM} / 74-04$

Publication date:March $31^{\text {st }} 2021$

\section{INTRODUCTION}

Government of Ethiopia have initiated watershed development since 1970's and 1980's respectively and increasingly been managed and developed for poverty alleviation and environmental conservation (Chimdesa, 2016).In Ethiopia 85 percent of the population are directly dependent on the agricultural economy. Watershed resource degradation is a serious problem in the Ethiopian which threatening agricultural development and rural livelihood. Since the economy of the country is agrarian in nature, the decline in agricultural productivity adversely affects the economic growth of the country. However, the productivity of that economy is being seriously eroded by unsustainable land management practices, both in areas of food crops and in grazing lands (FAO, 2016). The Government has been recognized that protection of watersheds cannot be achieved without the improving the livelihood of local people and taking lessons from the past shortcomings and it has been initiated community based watershed management (Habtamu, 2011). At socio-economic level a watershed includes people, their farming system and interactions with their land resources, coping strategies, social, economic and cultural aspects (Adane, 2010). Watershed management is the management of land and other resources on a watershed to achieve well-defined environmental, social, and economic goals. Watershed degradation, in turn, leads to accelerated ecological degeneration, reduced economic opportunities and increased social problems (Berry, 2016).

Most watershed interventions are implemented with the twin objectives of soil and water conservation and enhancing the livelihoods of the rural poor. Different types of treatment activities carried out in a watershed include soil and moisture conservation measures in agricultural lands (contour/ field bunding and summer ploughing), drainage line treatment measures (loose boulder check dam, minor check dam, major check dam, and retaining walls), water resource development/management (percolation pond, farm pond, and drip and sprinkler irrigation), crop demonstration, horticulture plantation and afforestation The aim has been to ensure the availability of drinking water, fuel wood and fodder and raise income and employment for farmers and landless labourers through improvement in agricultural production and productivity (Rao, 2017). 
Soil erosion is the main cause of land degradation and a leading factor contributing to poor agricultural development in developing countries (Gemechu 2016). Currently, soil resources are the main sources of livelihoods for most people of the world, such human exploitation being the foremost factor for soil degradation (Molla and Sisheber 2017). In developing countries, many people have been settled in the highlands due to favorable agricultural and ecological conditions, leading to high population densities and causing resource degradation (Haregeweyn et al. 2017; Nyssen et al. 2008).

The soils of the study area have been continuously cultivated and depleted. Although knowledge of soil physical and chemical properties plays a vital role in enhancing production and productivity on sustainable basis, there is limitation of knowledge and detail information on the characteristic features of soils around study area of Kechi District, Southern Ethiopia.

Thus, this study was to investigate the impacts of watershed intervention on the selected soil physicochemical properties of the study area. The findings of the study are expected to contribute to the improvement soil properties and to fill-in the knowledge gap in watershed management problems in the study area.

\section{MATERIAL AND METHODS \\ Description of the Study Area}

The study was conducted in Kechi District, Dawuro Zone of Southern Nations, Nationalities and People's Regional State (SNNPRS), Ethiopia. Geographically, the study area lies between $6^{\circ} 54^{\prime} 29.96^{\prime \prime}$ to $6^{\circ} 55^{\prime} 16.78^{\prime \prime} \mathrm{N}$ and $37^{\circ} 13^{\prime} 49.10^{\prime \prime}$ to $37^{\circ} 14^{\prime} 18.05^{\prime \prime}$ E. It is at about $500 \mathrm{~km}$ south west of Addis Ababa, the capital of Ethiopia. The woreda shares boundary with Gessa District in the east, Tocha District in north, Konta special woreda in the west, Loma District south east and Essera district in the south. The study area lies between 2286 and 2516 masl receiving a total annual rainfall range from 1355.4 to $2565.6 \mathrm{~mm}$ with mean monthly temperature varying from 11.7 to $23.5^{\circ} \mathrm{C}$. The rainfall is a bimodal type: the short rainy season is between March and May, and the long between June and September. According to Tefera et al. (1999), the geology of the study area is abundant with rhyolites and trachy basalts mainly overlying in the Precambrian basement and tertiary volcanism. Most of the area is mountainous, having well drained and moderately weathered brown soil (Nitisols) and Orthic Acrisols (BoPED, 1998

\section{Method of Data collection}

The impacts of Watershed intervention were evaluated using adjacent conserved and non-conserved plots in the kechi micro watershed. Sites having conserved and non-conserved plots adjacently were identified through reconnaissance survey. For several reasons, some plots had not been conserved adjacent to the conserved plots in different portions of the watershed. This was vital to make sample sites relatively similar in physical and environmental conditions for comparison and the variation could be due to watershed intervention measures. Soil samples were collected using $15-\mathrm{cm}$ depth auger and $294.375 \mathrm{~cm} 3$ core sampler at a depth of 0-30 cm. A total of 24 composite and core soil samples (two treatments [conserved and non-conserved plots] * two land uses * six replicates) were collected. Soil samples were collected from upstream, midstream, and downstream part of the watershed to make representative for the whole watershed. Soil samples from upper ( $0.5 \mathrm{~m}$ from the upper bund), middle (midpoint between two successive bunds), and lower $(0.5 \mathrm{~m}$ from the lower bund) part of two successive bunds were composited for conserved soil samples to make it more representative, because upper, middle, and lower portion of the area between terraces may have different soil fertility. One kilogram composite soil was packed from each soil sampling site for laboratory analysis. Purposive sampling was applied to select adjacent conserved and non-conserved watershed plots and to represent large area. Core samples were taken along with each composite sample. Samples from cultivated land were taken after crop harvest with similar crop land uses. 

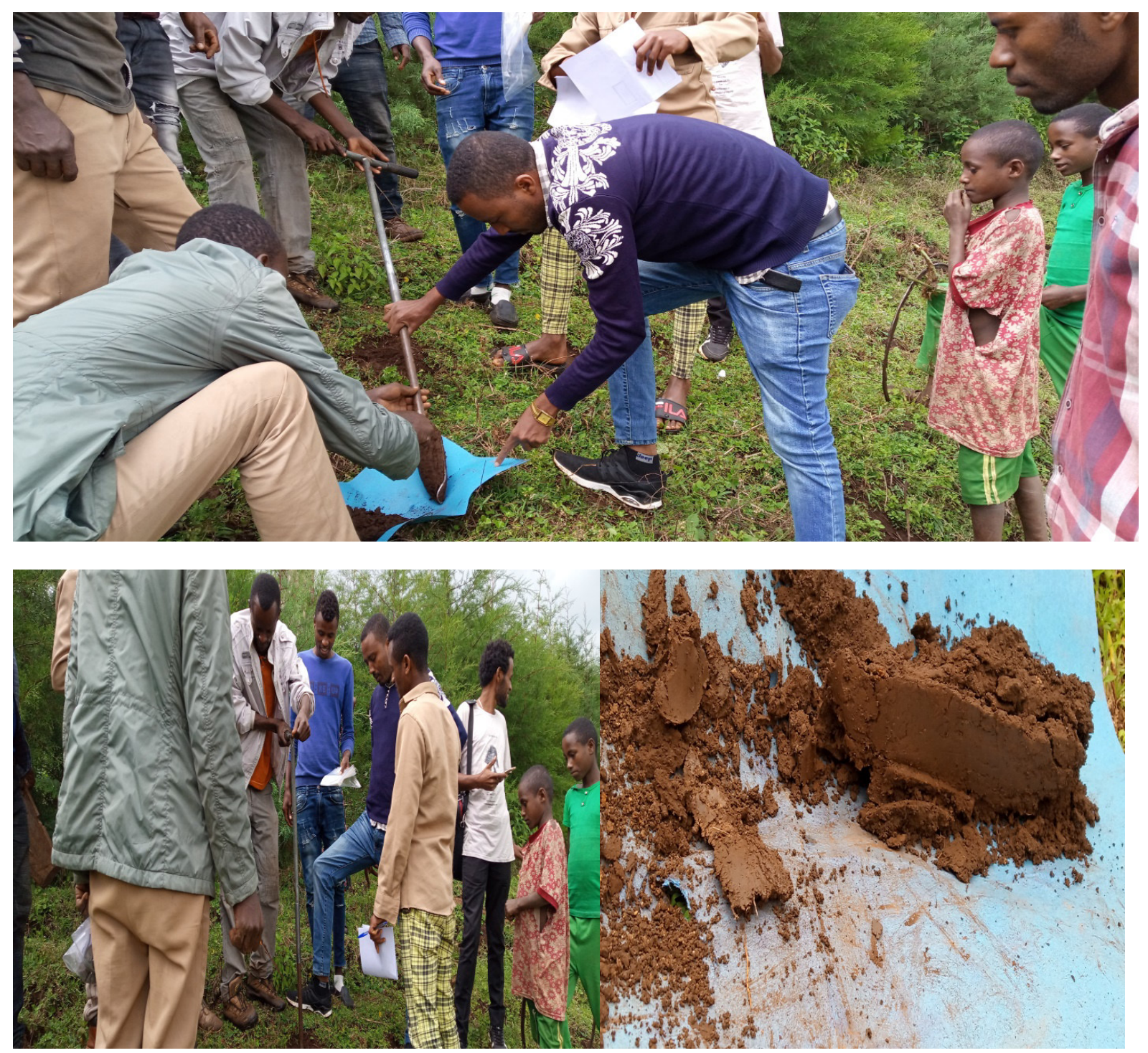

Photos taken during soil sample collection from representative soil samples in kechi micro watershe

\section{Soil Analysis}
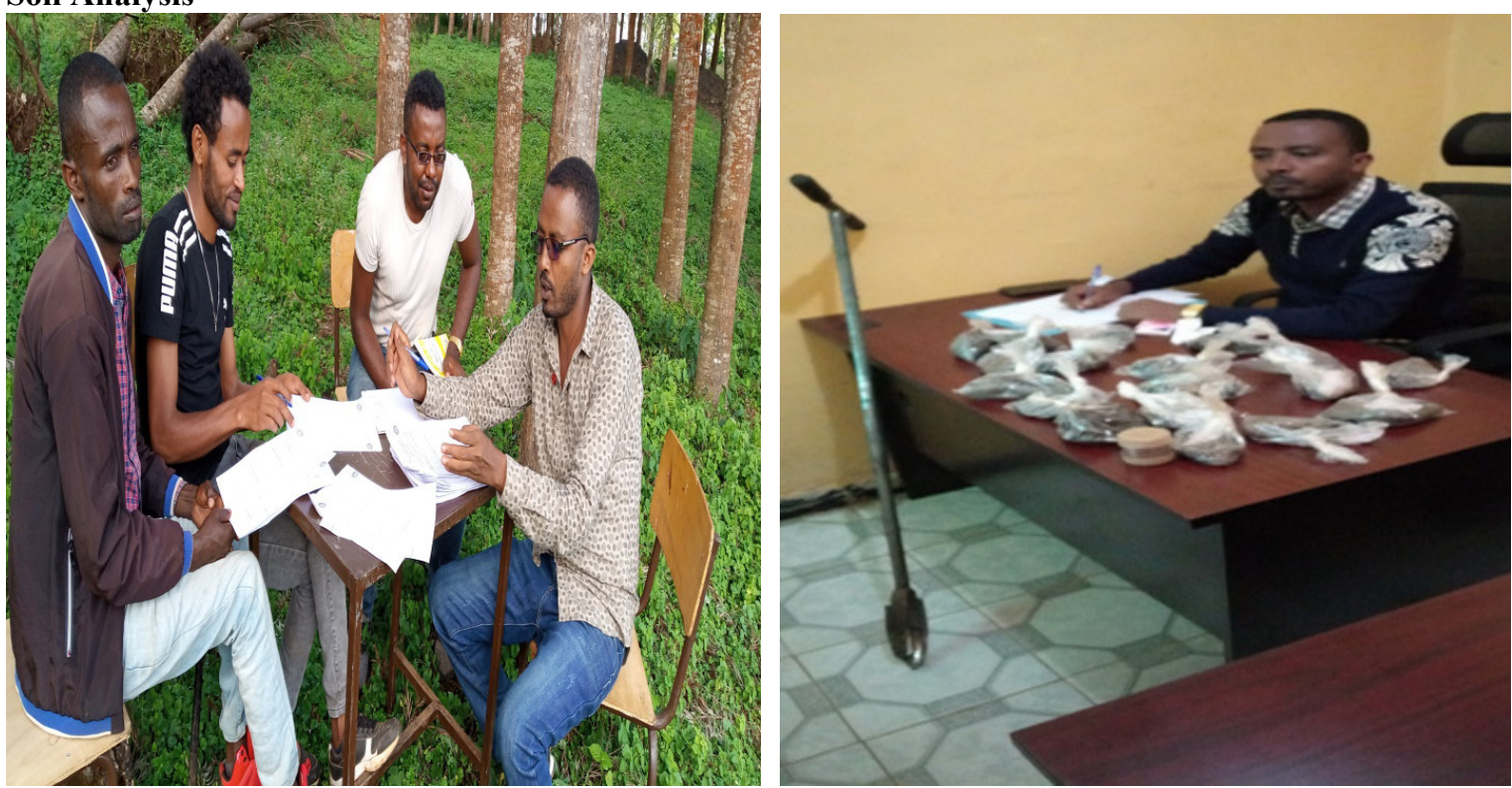
Composite soil samples were air-dried, grinded, and sieved to pass through a $2 \mathrm{~mm}$ sieve to make it ready for lab analysis. The soil laboratory analysis was done at Jimma Agricultural research center. Selected soil fertility indicators such as soil texture, soil $\mathrm{pH}$, bulk density, total nitrogen, organic carbon, available phosphorus, exchangeable bases, and caution exchange capacity were analyzed using standard laboratory procedures. For the analysis of total nitrogen and organic carbon content, the soil sample was further sieved by $0.5 \mathrm{~mm}$ sieve. The soil bulk density was determined by core sampler method described in Black et al. (1965). The determination of soil particle size proportions were carried out by hydrometer method suggested by Sakar and Haldar (2005). Following this, the determination of soil texture and textural classification ware identified using equilateral triangle suggested by United States Department of Agriculture (USDA) and described by Osman (2013). Soil reaction (soil $\mathrm{pH}$ ) was determined by a 1:2.5 soil: water ratio using a $\mathrm{pH}$ meter as described by Van Reeuwijk (2002). The soil organic carbon (SOC) concentration was determined by using Walkley and Black rapid titration method as described in Sakar and Haldar (2005). Soil organic matter (SOM) was determined by multiplying percent organic carbon by 1.724 (Jones 2001). Total nitrogen (TN) was determined by the modified Kjeldahl methods as modified by Sakar and Haldar (2005). The available phosphorus (av. P) content was determined using Olsen extraction method as described by Van Reeuwijk (2002). The exchangeable bases and CEC were determined by using ammonium acetate method (Sakar and Haldar 2005). Ca2 + and Mg2 + were determined by atomic absorption spectrophotometer; flame photometer method was used for determination of $\mathrm{Na}+$ and $\mathrm{K}$

\section{Statistical analysis}

Mean and mean differences were used as a descriptive statistical analysis method. One-way ANOVA was used to test whether there is a significant difference in soil physicochemical properties between conserved and nonconserved plots. Two-way ANOVA was applied to test whether soil properties are affected significantly due to the interaction effect of land uses and SWC treatment. In addition, bivariate correlation analysis was used to show the relationships between soil physicochemical properties.

\section{RESULTS AND DISCUSSION \\ Selected Soil Physical Properties under Different Land Use Types Soil particle size distributions}

The textural classes were identified using soil equilateral triangle recommended by USDA and described by Osman (2013). Accordingly, the mean particle size proportion showed that the soil was fine textured in conserved and non-conserved plots. The soil in the study area has been dominated by clay content experiencing a mean value of $67.8 \%$ and $60.5 \%$ in conserved and non-conserved soil respectively (Table 1), which implies that the mean value of clay content was higher under conserved plots. The mean sand fraction is the lowest proportion of soil particle content in the area. It was also indicated that the mean sand fraction was relatively lower in conserved plots. This might be attributed to the relative effect of SWC on soil erosion, which reduces the removal of top fine soil particles. On the contrary, higher sand content of the soil in non-conserved plots may be resulted due to removal of fine particles via soil erosion. A land that receives a high amount of rainfall and continuously cultivated without any conservation measure could allow free and easy removal of fine particles via rainfall runoff. The silt content of the soil was higher in non-conserved plots against the conserved plots. However, the differences in the mean soil particle size distribution (sand, clay, and silt) among conserved and non-conserved plots were not statistically significant at $\mathrm{p}<0.05$ (Table 1 ).

\section{Soil bulk density}

The effect of watershed intervention on the mean soil bulk density was found to be minimal and slightly lower values were observed in conserved plots. A relatively higher bulk density in non-conserved plots could be related with washing out of fine organic matter rich soils by erosion and thereby exposed slightly heavier soil particulates. The ANOVA result indicated that the variation in bulk density was not statistically significant following treatment $(\mathrm{p}<0.05$; Table 2$)$. 
Table 1 Test of normality and homogeneity of variance for soil physical and chemical properties in both land uses and per micro watershed

\begin{tabular}{|c|c|c|c|c|c|c|}
\hline \multirow[t]{2}{*}{ Soil properties } & \multicolumn{2}{|c|}{$\begin{array}{l}\text { Both land uses } \\
(\mathrm{n}=24)\end{array}$} & \multicolumn{2}{|c|}{$\begin{array}{l}\text { Cultivated land } \\
\qquad(\mathrm{n}=12)\end{array}$} & \multicolumn{2}{|c|}{$\begin{array}{l}\text { Grazing land } \\
(n=12)\end{array}$} \\
\hline & Tura & Tuta & Tura & Tuta & Tura & Tuta \\
\hline PH $\left(\mathrm{H}_{2} \mathrm{O}\right)$ & $0.35^{\mathrm{ns}}$ & $3.94^{\mathrm{ns}}$ & $0.627^{\mathrm{ns}}$ & $0.400^{\mathrm{ns}}$ & $0.318^{\mathrm{ns}}$ & \\
\hline SOC (\%) & $0.272^{\mathrm{ns}}$ & $0.002 *$ & $0.496^{\mathrm{ns}}$ & $0.629^{\mathrm{ns}}$ & $0.111^{\mathrm{ns}}$ & $0.152^{\mathrm{ns}}$ \\
\hline TN (\%) & $0.269^{\mathrm{ns}}$ & $0.102^{\mathrm{ns}}$ & $0.507^{\mathrm{ns}}$ & $0.487^{\mathrm{ns}}$ & $0.143^{\mathrm{ns}}$ & $0.941^{\mathrm{ns}}$ \\
\hline Bulk density $\left(\mathrm{gcm}^{3}\right)$ & $0.446^{\mathrm{ns}}$ & $0.053^{\mathrm{ns}}$ & $0.285^{\mathrm{ns}}$ & $0.661^{\mathrm{ns}}$ & $0.645^{\mathrm{ns}}$ & $0.659^{\mathrm{ns}}$ \\
\hline Sand(\%) & $0.811^{\mathrm{ns}}$ & $0.021^{\mathrm{ns}}$ & $0.391^{\mathrm{ns}}$ & $0.084^{\mathrm{ns}}$ & $0.086^{\mathrm{ns}}$ & $0.139^{\mathrm{ns}}$ \\
\hline Clay(\%) & $0.571^{\mathrm{ns}}$ & $0.049^{\mathrm{ns}}$ & $0.467^{\mathrm{ns}}$ & $0.042 *$ & $0.331^{\mathrm{ns}}$ & $0.117^{\mathrm{ns}}$ \\
\hline Silt (\%) & $0.433^{\mathrm{ns}}$ & $0.014 *$ & $0.468^{\mathrm{ns}}$ & $0.605^{\mathrm{ns}}$ & $0.080^{\mathrm{ns}}$ & $0.036^{*}$ \\
\hline Av.P (ppm) & $0.344^{\mathrm{ns}}$ & $0.021 *$ & $0.919^{\mathrm{ns}}$ & $0.391^{\mathrm{ns}}$ & $0.972^{\mathrm{ns}}$ & $0.517^{\mathrm{ns}}$ \\
\hline $\begin{array}{l}\text { CEC and Each cations }\left(\mathrm{cmol}^{(+)} \mathrm{kg}-1\right) \\
\text { CEC }\end{array}$ & $0.608^{\mathrm{ns}}$ & $0.808^{\mathrm{ns}}$ & $0.475^{\mathrm{ns}}$ & $0.987^{\mathrm{ns}}$ & $0.425^{\mathrm{ns}}$ & $0.219^{\mathrm{ns}}$ \\
\hline $\mathrm{Na}^{+}$ & $0.091^{\mathrm{ns}}$ & $0.223^{\mathrm{ns}}$ & $0.907^{\mathrm{ns}}$ & $0.071^{\mathrm{ns}}$ & $0.104^{\mathrm{ns}}$ & $0.770^{\mathrm{ns}}$ \\
\hline $\mathbf{K}^{+}$ & $0.83^{\mathrm{ns}}$ & $0.143^{\mathrm{ns}}$ & $0.876^{\mathrm{ns}}$ & $0.200^{\mathrm{ns}}$ & $0.797^{\mathrm{ns}}$ & $0.910^{\mathrm{ns}}$ \\
\hline $\mathrm{Ca}^{2+}$ & $0.972^{\mathrm{ns}}$ & $0.474^{\mathrm{ns}}$ & $0.898^{\mathrm{ns}}$ & $0.545^{\mathrm{ns}}$ & $0.934^{\mathrm{ns}}$ & $0.102^{\mathrm{ns}}$ \\
\hline $\mathrm{Mg}^{2+}$ & $0.614^{\mathrm{ns}}$ & $0.385^{\mathrm{ns}}$ & $0.867^{\mathrm{ns}}$ & $0.476^{\mathrm{ns}}$ & $0.360^{\mathrm{ns}}$ & $0.425^{\mathrm{ns}}$ \\
\hline
\end{tabular}

Av.P available phosphorus, CEC cation exchange capacity, ns not significant at $\mathrm{p}<0.005, \mathrm{p} p$ value, SOC soil organic carbon, $*$ significant at $\mathrm{p}<0.005, \mathrm{TN}$ total nitrogen.

\section{The Impact of watershed intervention on soil chemical properties}

Soil reaction (soil pH)

The acidity level of the watershed in general was rated as medium acidic based on Osman (2013) acidity and alkalinity categories of soil $\mathrm{pH}$. The mean $\mathrm{pH}$ of the soil in the study watershed was 5.77 and 5.66 in conserved and non-conserved land respectively (Table 2). The acidity of the soil could be related with its sub-humid nature of the area and high amount of rainfall. This is true that greater rainfall increases soil acidity and humid areas are more acidic than arid and semi-arid areas (Osman 2013).

\section{Soil organic carbon (SOC) and soil organic matter (SOM)}

The analysis of variance result for SOC and SOM showed a statistically significant mean difference following treatments $(\mathrm{p}<0.05$; Table 3$)$. The mean organic carbon and organic matter content of the soil in conserved plots were higher $(\mathrm{SOC}=2.49 \%, \mathrm{SOM}=4.3 \%)$ than non-conserved plots $(\mathrm{SOC}=1.66 \%, \mathrm{SOM}=2.83 \%)$. Besides, the mean soil organic carbon (SOC) content was rated low in conserved and very low in non-conserved plots according to the rating standard developed for tropical soils (Landon 2013). It could be explained by soil erosion, continuous cultivation, harvesting crop residues, and animal dung. The use of animal dung for fuel instead of manure may reduce the effectiveness of SWC practices in SOC concentration (Mengistu et al. 2016).

\section{Total nitrogen}

The total nitrogen $(\mathrm{TN})$ content of the soil was significantly affected by SWC practices ( $\mathrm{p} \mathrm{p}<0.01$; Table 3 ). TN content of the soil in Kechi watershed was rated medium and low in conserved and non-conserved plots respectively (Landon 2013). The mean total nitrogen of the soil was greater in conserved $(0.27 \%)$ than nonconserved plots $(0.138 \%)$.

Table 2 the mean and their significant variations (one-way ANOVA) of soil physical properties in kechi micro Watershed

\begin{tabular}{|c|c|c|c|c|c|c|c|}
\hline & \multicolumn{4}{|c|}{ Soil particle size proportions } & \multirow{2}{*}{$\begin{array}{l}\text { Soil } \\
\text { texture }\end{array}$} & \multirow{2}{*}{$\begin{array}{c}\text { Soil } \\
\text { textural } \\
\text { class }\end{array}$} & \multirow{2}{*}{$\begin{array}{c}\text { Bulk } \\
\text { density } \\
(\text { gcm } 3)\end{array}$} \\
\hline & & $\begin{array}{l}\text { Sand } \\
(\%)\end{array}$ & Clay $(\%)$ & Silt (\%) & & & \\
\hline \multirow[t]{4}{*}{ Treatment } & Conserved & 761 & 645 & 187 & Fine & Clay & 1.250 \\
\hline & Non-conserved & 87 & 557 & 243 & Fine & Clay & 1.247 \\
\hline & F ratio & 643 & 950 & 1178 & & Clay & .002 \\
\hline & $\mathrm{P}$ & .265 & .18 & .267 & - & - & .963 \\
\hline
\end{tabular}

Source Author, 2021 
Table 3. The mean and their significant variations (one way ANOVA) of soil chemical properties in conserved and non-conserved Micro watershed

\begin{tabular}{|c|c|c|c|c|c|c|c|c|c|c|c|}
\hline & & & & & & & \multicolumn{5}{|c|}{ CEC and Each cations $\left(\mathrm{cmol}^{(+)} \mathrm{kg}-1\right)$} \\
\hline & & $\begin{array}{l}\mathrm{PH} \\
\left(\mathrm{H}_{2} \mathrm{O}\right)\end{array}$ & $\begin{array}{l}\mathrm{SOC} \\
(\%)\end{array}$ & $\begin{array}{l}\text { SOM } \\
(\%)\end{array}$ & $\begin{array}{l}\mathrm{TN} \\
(\%)\end{array}$ & $\begin{array}{l}\text { Av.P } \\
(\mathrm{ppm})\end{array}$ & CEC & $\mathrm{Na}^{+}$ & $\mathrm{K}^{+}$ & $\mathrm{Ca}^{2+}$ & $\mathrm{Mg}^{2+}$ \\
\hline \multirow{4}{*}{ Treatment } & Conserved & 5.54 & 2.46 & 4.2 & .270 & 6.96 & 33.4 & 31 & .52 & 19.3 & 8.67 \\
\hline & $\begin{array}{l}\text { Non } \\
\text { conserved }\end{array}$ & 5.34 & 1.67 & 2.76 & .136 & 7.9 & 31.9 & .18 & .46 & 21.4 & 5.45 \\
\hline & F ratio & 0.67 & 4.367 & 4.357 & 8.503 & .354 & .186 & 12.35 & 361 & .453 & 8.525 \\
\hline & $\mathrm{P}$ & 0.381 & $0.046^{*}$ & $0.046^{*}$ & $.008 * *$ & $.558 *$ & .663 & $.002 * *$ & .553 & .523 & $.005^{* *}$ \\
\hline
\end{tabular}

Source Author, 2021

\section{Available phosphorous}

Available phosphorous of the soil was not significantly affected by conservation measures $(\mathrm{p}>0.05)$. Its mean value was lower in conserved plots $(6.96 \mathrm{ppm})$ as compared to non-conserved plots $(7.9 \mathrm{ppm})$ (Table 3$)$. The varations in the use of artificial fertilizer (diammonium phosphate) may be the reason for the previaled varations in the soil. As compared to the requirements of crops that have been dominantly practiced in the area, the phosphorous content of the soil was questionable $(4.1-8 \mathrm{ppm})$ and deficient $(<11 \mathrm{ppm})$ for low demand crops (such as cereals and maize) and high demand crops (such as potatoes, onions) respectively (Landon 2013).

\section{Cation exchange capacity}

According to the rating standards of Landon (2013), the cation exchange capacity (CEC) of the soil in kechi micro watershed was rated as high $(25-40 \mathrm{cmol}(+) \mathrm{kg}-1$ ) in both conserved and non-conserved micro watershed. The study result revealed that watershed intervention had a positive effect on the CEC content of the soil. The mean difference was higher in Tura $(33.6 \mathrm{cmol}(+) \mathrm{kg}-1)$ than Tuta $(31.9 \mathrm{cmol}(+) \mathrm{kg}-1)$ (Table 3$)$, but not statistically significant $(\mathrm{p}>0.05)$. This is believed to be caused by the relative effect of conservation measures in the watershed.

\section{Exchangeable cations $(\mathrm{Na}+, \mathrm{K}+, \mathrm{Ca} 2+$, and $\mathrm{Mg} 2+)$}

The relative abundance of basic cations in the exchange complex was $\mathrm{Na}+<\mathrm{K}+<\mathrm{Mg} 2+<\mathrm{Ca} 2+$ for both conserved and non-conserved soils. Exchangeable $\mathrm{Ca} 2+(19.3 \mathrm{cmol}(+) \mathrm{kg}-1,21.4 \mathrm{cmol}(+) \mathrm{kg}-1)$ and $\mathrm{Na}+$ $(0.31 \mathrm{cmol}(+) \mathrm{kg}-1,0.18 \mathrm{cmol}(+) \mathrm{kg}-1)$ constitutes the highest and lowest proportion in Tura and Tuta micro watershed respectively (Table 3 ). One-way analysis of variance result for exchangeable $\mathrm{Na}+$ and $\mathrm{Mg} 2+$ showed a statistically significant difference $(\mathrm{p}<0.01)$ between conserved and non-conserved micro watershed. By contrast, the effect of conservation practices for exchangeable $\mathrm{Ca} 2+$ and $\mathrm{K}+$ was not statistically significant $(\mathrm{p}>$ $0.05)$.

\section{The effectiveness of Watershed intervention in different land uses}

As shown in Table 4, the analysis of variance result for the mean differences of all soil particle size distributions was not significantly affected by conservation practices in both land uses $(p>0.05)$. However, mean differences were observed in cultivated and grazing land uses following treatments. The highest sand fraction was recorded from non-conserved cultivated land and lowest in conserved grazing land. The mean clay content of the soil was $65.67 \%$ and $62 \%$ in v cultivated plots. The mean difference for bulk density was slightly higher in cultivated land, with higher mean values in the non-conserved than in the conserved land (Table 4). It was not the case for grazing land uses, in which conserved plots experience higher mean values than non-conserved plots. The ANOVA result indicated that the variation in bulk density was not statistically significant between the conserved and non-conserved lands for either cultivated or grazing land uses due to watershed intervention $(\mathrm{p}>0.05$; Table 4). The influence of land use on the effect of conservation measures for the mean difference of soil $\mathrm{pH}$ was slight. Higher SOC concentration was observed in grazing land uses than in cultivated land uses. Our analysis result by land use revealed that the mean difference in SOC and SOM was higher and statistically significant $(p<0.05)$ between conserved and non-conserved cultivated land uses. Higher TN content of the soil was observed in Tura grazing land uses $(0.32 \%)$ followed by Tura cultivated land uses $(0.219 \%)$ and non-conserved cultivated lands constitute the lowest $(0.105 \%)$ (Table 5$)$. The ANOVA result revealed a significant effect on effectiveness of conservation measures on cultivated plots at $\mathrm{p}<0.01$. Conversely, conservation measures did not show a statistically significant variation for SOM, SOC, and TN in grazing lands $(\mathrm{p}<0.05)$. The SWC treatments for available phosphorous were not significantly affected by land uses $(p>0.05)$. Instead, greater concentrations were observed in Tuta $(9.755 \mathrm{ppm})$ than in Tura cultivated land $(7.78 \mathrm{ppm})$ (Table 5). Grazing land uses revealed very small mean difference for available phosphorous following watershed interventions. The use of inorganic 
fertilizer (diammonium phosphate) to enhance crop production in cultivated land could probably increase av. P concentrations in cultivated plots. The CEC content of the soil in conserved and non-conserved land uses revealed $31.97 \mathrm{cmol}(+) \mathrm{kg}-1,35.3 \mathrm{cmol}(+) \mathrm{kg}-1$ in cultivated land and $29.56 \mathrm{cmol}(+) \mathrm{kg}-1,34.3 \mathrm{cmol}(+)$ $\mathrm{kg}-1$ in grazing land respectively (Table 5). The influence of conservation structures on CEC was not determined by land uses and the mean difference was not statistically significant for both land uses. However, the impact of watershed intervention has been better in cultivated land uses as compared to grazing land uses. The effect of watershed intervention in cultivated and grazing land uses showed a statistically significant difference in exchangeable $\mathrm{Na}+$ for both land uses $(\mathrm{p}<0.05)$ and exchangeable $\mathrm{Mg} 2+$ only in cultivated land use $(\mathrm{p}<0.01)$. A two-way between groups analysis of variance was conducted to explore the impact of SWC treatment and land use types on soil fertility variation. The result showed a statistically significant main effect for SWC treatment on SOC, SOM at $\mathrm{p}<0.05$, and TN, Na+, and $\mathrm{Mg} 2+$ at $\mathrm{p}<0.01$. The main effect for land uses was statistically significant only for SOC, SOM, and bulk density at $p<0.05$. However, the interaction effect of watershed intervention and land uses did not show a statistically significant mean difference for any of the selected soil fertility indicators ( $\mathrm{p}<0.05$; Table 6).

Table 4 the effect of SWC practices on soil physical properties in different land uses (cultivated and grazing land)

\begin{tabular}{|c|c|c|c|c|c|c|c|}
\hline & & \multicolumn{3}{|c|}{ Soil particle size proportions } & \multirow{2}{*}{$\begin{array}{l}\text { Soil } \\
\text { texture }\end{array}$} & \multirow{2}{*}{$\begin{array}{l}\text { Soil } \\
\text { textural } \\
\text { class }\end{array}$} & \multirow{2}{*}{$\begin{array}{l}\text { Bulk } \\
\text { density } \\
\text { (g cm-3) }\end{array}$} \\
\hline & & Sand $(\%)$ & Clay $(\%)$ & Silt $(\%)$ & & & \\
\hline \multirow[t]{4}{*}{ Cultivated land } & $\mathrm{CL}$ & 9.333 & 65.67 & 25 & Fine & Clay & 1.29 \\
\hline & NCL & 11 & 62 & 27 & Fine & Clay & 1.318 \\
\hline & F ratio & .312 & .258 & .098 & Fine & Clay & .846 \\
\hline & $\mathrm{p}$ & $.589 \mathrm{~ns}$ & $.623 \mathrm{~ns}$ & $.76 \mathrm{~ns}$ & & & $.379 \mathrm{~ns}$ \\
\hline \multirow[t]{4}{*}{ Grazing land } & $\mathrm{CL}$ & 6.33 & 70 & 23.7 & Fine & Clay & 1.21 \\
\hline & NCL & 9.67 & 59 & 31.3 & Fine & Clay & 1.18 \\
\hline & F ratio & .509 & 1.76 & 1.509 & Fine & Clay & .122 \\
\hline & $\mathrm{p}$ & $.492 \mathrm{~ns}$ & $.214 \mathrm{~ns}$ & $.247 \mathrm{~ns}$ & & - & $.734 \mathrm{~ns}$ \\
\hline
\end{tabular}

CL conserved land, NCL non-conserved land, $\mathrm{P} p$ value, ns not significant at $\mathrm{p}<0.05$

Table 5 the effect of SWC practices on soil chemical properties in different land uses (cultivated and grazing land)

\begin{tabular}{|c|c|c|c|c|c|c|c|c|c|c|c|}
\hline & & \multirow{2}{*}{$\begin{array}{l}\text { PH } \\
\text { (H2O) }\end{array}$} & \multirow{2}{*}{$\begin{array}{l}\text { SOC } \\
(\%)\end{array}$} & \multirow{2}{*}{$\begin{array}{l}\text { SOM } \\
(\%)\end{array}$} & \multirow{2}{*}{$\begin{array}{l}\text { TN } \\
(\%)\end{array}$} & \multirow{2}{*}{$\begin{array}{l}\text { Av. P } \\
(\text { ppm) }\end{array}$} & \multicolumn{5}{|c|}{ CEC and Exch. cations [cmol( + ) kg-1] } \\
\hline & & & & & & & CEC & $\mathrm{Na}+$ & $\mathrm{K}+$ & $\mathrm{Ca} 2+$ & $\mathrm{Mg} 2+$ \\
\hline \multirow{4}{*}{$\begin{array}{l}\text { Cultivated } \\
\text { land }\end{array}$} & $\mathrm{CL}$ & 5.712 & 3.494 & .219 & 7.778 & 7.778 & 31.97 & .305 & .562 & 17.13 & 8.817 \\
\hline & NCL & 5.6 & 1.248 & 2.152 & .105 & 9.755 & 29.56 & .178 & .463 & 19.1 & 5.25 \\
\hline & $\begin{array}{l}\mathrm{F} \\
\text { ratio }\end{array}$ & .316 & 11.577 & 11.577 & 12.607 & .474 & .301 & 5.346 & .545 & .223 & 14.101 \\
\hline & $\mathrm{p}$ & $.586 \mathrm{~ns}$ & $.007 * *$ & $.007 * *$ & $.005 * *$ & $.507 \mathrm{~ns}$ & $.595 \mathrm{~ns}$ & $.043 *$ & $\begin{array}{l}.477 \\
\mathrm{~ns}\end{array}$ & $\begin{array}{l}.647 \\
\mathrm{~ns}\end{array}$ & $.004^{* *}$ \\
\hline \multirow{4}{*}{$\begin{array}{l}\text { Grazing } \\
\text { land }\end{array}$} & CL & 5.82 & 2.96 & 5.1 & .320 & 6.13 & 35.3 & 5.82 & .32 .47 & 21.4 & 8.55 \\
\hline & NCL & 5.72 & 2.07 & 2.07 & 3.56 & .172 & 6.05 & 34.3 & .18 .47 & 23.7 & 6.48 \\
\hline & $\begin{array}{l}\mathrm{F} \\
\text { ratio }\end{array}$ & .461 & 1.647 & 1.647 & 3.408 & .006 & .021 & 5.93 & 003 & .205 & 1.638 \\
\hline & $\mathrm{p}$ & $.512 \mathrm{~ns}$ & $.228 \mathrm{~ns}$ & $.228 \mathrm{~ns}$ & $.095 \mathrm{~ns}$ & $.941 \mathrm{~ns}$ & $.886 \mathrm{~ns}$ & $.035^{*}$ & $.958 \mathrm{~ns}$ & $.66 \mathrm{~ns}$ & $.229 \mathrm{~ns}$ \\
\hline
\end{tabular}

Av. P available phosphorous, CEC cation exchange capacity, CL conserved land, NCL non-conserved land, ns not significant at $\mathrm{p}<0.05, \mathrm{P} \mathrm{p}$ value, SOC soil organic carbon, SOM soil organic matter; **** significantly different at $\mathrm{p}<0.01$ and $\mathrm{p}<0.05$ respectively (two-tailed); TN total nitrogen 
Table 6. The two-way ANOVA result showing the interaction effect of land uses and SWC treatment on soil physicochemical properties

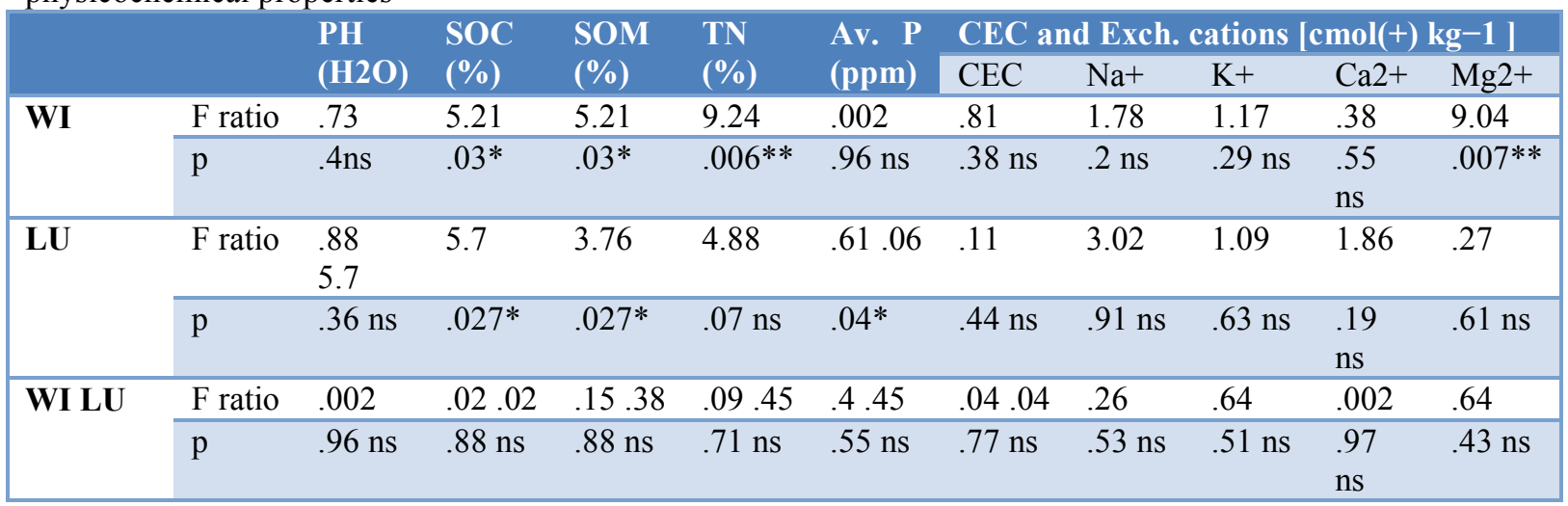

Av. P available phosphorous, BD bulk density, CEC cation exchange capacity, LU land use, ns not significant at $\mathrm{p}<0.05$, P $\mathrm{p}$ value, SOC soil organic carbon, SOM soil organic matter; $* * *$ significantly different at $\mathrm{p}<0.01$ and $\mathrm{p}<0.05$ respectively (two-tailed); WI watershed intervention, TN total nitrogen

The interrelationship among soil physicochemical properties

The simple linear correlation (Pearson) results revealed the strength and magnitude of relationship among physicochemical properties. The $\mathrm{pH}$ of the soil showed a positive significant relationship with $\mathrm{SOM}\left(0.673^{* *}\right)$, TN $\left(0.628^{* *}\right)$, CEC $\left(0.619^{* *}\right)$, and all exchangeable bases except magnesium (Table 7). It also showed significantly negative relationship with $\mathrm{BD}\left(-0.426^{*}\right)$. The correlation matrix further revealed a positive very strong significant relationship $\left(0.959^{* *}\right)$ between $\mathrm{TN}$ and SOM and strong positive significant correlation $\left(0.7^{* *}\right.$, $\left.0.783^{* *}, 0.734^{* *}\right)$ with $\mathrm{CEC}$, exchangeable $\mathrm{Na}+$, and $\mathrm{Mg} 2+$ content. Similarly, bulk density showed strong negative significant relationship $\left(-0.702 * *,-0.756^{* *},-0.747^{* *}\right)$ with $\mathrm{OM}, \mathrm{CEC}$, and exchangeable $\mathrm{Ca} 2+$ content of the soil respectively. However, available phosphorous showed no regular trends and weakly varied with other soil physicochemical properties in kechi micro watersheds (Table 7).

Table 7 The relationship (Pearson's product movement coefficient of correlation) between soil physicochemical properties

\begin{tabular}{|c|c|c|c|c|c|c|c|c|c|c|c|c|c|c|c|}
\hline & & \multirow{2}{*}{$\begin{array}{l}\text { PH } \\
\text { (H2O) }\end{array}$} & \multirow{2}{*}{$\begin{array}{l}\text { SOC } \\
(\%)\end{array}$} & \multirow{2}{*}{$\begin{array}{l}\text { SOM } \\
(\%)\end{array}$} & \multirow[t]{2}{*}{ TN (\%) } & \multirow{2}{*}{$\begin{array}{l}\text { BD } \\
(\mathrm{g} \mathrm{cm}-3)\end{array}$} & \multirow{2}{*}{$\begin{array}{l}\text { Sand } \\
(\%)\end{array}$} & \multirow{2}{*}{$\begin{array}{l}\text { Clay } \\
(\%)\end{array}$} & \multirow{2}{*}{$\begin{array}{l}\text { Silt } \\
(\%)\end{array}$} & \multirow{2}{*}{$\begin{array}{l}\text { Av. P } \\
(\mathrm{ppm})\end{array}$} & \multicolumn{5}{|c|}{$\mathrm{CEC}$ and Exch. cations [emol $(+) \mathrm{kg}-1]$} \\
\hline & & & & & & & & & & & CEC & $\mathrm{Na}+$ & $\mathrm{K}+$ & $\mathrm{Ca} 2+$ & $\mathrm{Mg} 2+$ \\
\hline \multicolumn{2}{|l|}{ PH (H2O) } & 1 & & & & & & & & & & & & & \\
\hline \multicolumn{2}{|l|}{ SOC $(\%)$} & $673^{* *}$ & 1 & & & & & & & & & & & & \\
\hline \multicolumn{2}{|l|}{ SOM (\%) } & $.673^{* *}$ & $1.000^{* *}$ & 1 & & & & & & & & & & & \\
\hline \multicolumn{2}{|l|}{ TN (\%) } & $.628^{* *}$ & $.959^{* *}$ & $.959 * *$ & 1 & & & & & & & & & & \\
\hline \multicolumn{2}{|l|}{ BD(g cm-3) } & $.426^{*}$ & $-.702 * *$ & $-.702 * *$ & $-.661 * *$ & 1 & & & & & & & & & \\
\hline \multicolumn{2}{|l|}{ Sand (\%) } & -.248 & -.403 & -.403 & $-.481^{*}$ & $.598^{* *}$ & 1 & & & & & & & & \\
\hline \multirow{2}{*}{\multicolumn{2}{|c|}{$\begin{array}{l}\text { Clay (\%) } \\
\text { Silt (\%) }\end{array}$}} & .230 & .354 & .354 & $.461^{*}$ & $-.417^{*}$ & $-.608^{* *}$ & 1 & & & & & & & \\
\hline & & .133 & -.192 & -.192 & -.277 & .150 & .140 & $-.871^{* *}$ & 1 & & & & & & \\
\hline \multicolumn{2}{|l|}{ Av. $\mathbf{P}(\mathbf{p p m})$} & .232 & -.221 & -.221 & -.227 &. .212 & .029 & -.102 & -.145 & 1 & & & & & \\
\hline \multirow{5}{*}{$\begin{array}{l}\text { CEC\&Exch. } \\
\text { cations } \\
{[\text { cmol(+) }} \\
\text { kg-1 ] }\end{array}$} & CEC & $.619 * *$ & $.765^{* *}$ & $.765^{* *}$ & $.699^{* *}$ & $-.756 * *$ & $-.425^{*}$ & .339 & -.160 & .083 & 1 & & & & \\
\hline & $\mathrm{Na}+$ & $.640^{* *}$ & $.756^{* *}$ & $.756^{* *}$ &. $.783^{* *}$ & $-.496 *$ & $-.504 *$ & $.463^{*}$ & -.266 & .093 &. $.763^{* *}$ & 1 & & & \\
\hline & $\mathrm{K}+$ & .188 & .115 & .115 & .082 & -.228 & -.257 & -.130 & .321 & -.053 & .232 & .331 & 1 & & \\
\hline & $\mathrm{Ca} 2+$ & $.669 * *$ & $.641^{* *}$ & $.641^{* *}$ & $.553^{* *}$ & $-.747 * *$ & $-.428^{*}$ & .261 & -.061 & .183 & $.931 * *$ & $.621^{* *}$ & .179 & .1 & \\
\hline & $\mathrm{Mg} 2+$ & $.505^{*}$ & $.741^{* *}$ & $.741^{* *}$ & $.734^{* *}$ & $-.501^{*}$ & -.304 & .295 & -.180 & -.073 & $.768^{* *}$ & $.807^{* *}$ & .380 & $.529^{* *}$ & 1 \\
\hline
\end{tabular}

Av. P available phosphorous, BD bulk density, CEC cation exchange capacity, SOC soil organic carbon, SOM soil organic matter; ${ }^{* *},{ }^{*}$ the correlation is significant at $\mathrm{p}<0.01$ and $\mathrm{p}<0.05$ respectively (two-tailed); TN total nitrogen

\section{Discussion}

\section{The impact of soil and water conservation practices on soil properties}

Watershed intervention implemented in the Kechi micro-watershed has improved the soil condition as a result of reduction in runoff and sediment transport. This is indicated by the significant variations in soil physicochemical properties between conserved and non-conserved plots. SWC structures decreased the slope length and steepness and consequently led to better infiltration, slow movement, and less accumulation of runoff. As a result, the removal of soil particles, crop residues, and other organic components can be limited, which improves the soil condition as compared to the non-conserved soils. The particle size proportion of the soil was fine textured in both conserved and non-conserved soils. The soil of the watershed was dominated by clay content indicating relatively higher mean value in conserved plots. Similarly, Mengistu et al. (2016) reported higher mean clay content in the conserved Minchit than in non-conserved Zikire sub-watershed. Higher soil erosion, removal of fine materials, clay contents, and organic matter could be possible reasons for relativly lower clay content in non-conserved plots. Clay contents are fine particulates and more vulnerable to be washed out by erosion unless treated with SWC measures (Hishe et al. 2017; Selassie et al. 2015). A clay soil has an inherent advantage of 
good water and nutrient holding capacity and low level of leaching (Osman 2013). This nature of the soil helps the area to be more productive, even though it has been influenced by high soil erosion, continuous cultivation, and other natural and manmade influences. However, significant variation was not observed between conserved and non-conserved plots. This might be related with the prevailing parent materials and its inherent properties; such nature of the soil determines the texture of a soil, even if erosion, deposition, and other human activities may modify (Osman 2013). SWC practices affected the bulk density of the soil in kechi watershed. A relatively higher bulk density in non-conserved plots could be related with washing out of fine organic matter-rich soils by erosion and thereby exposing slightly heavier soil particles. On the other side, several potential causes may explain lower bulk density in conserved plots such as lesser effects of soil erosion (SWC structures as a barrier) and relatively higher SOM content resulted from accumulation of crop residues decay, plant leaves' decay, and less vulnerability for easy removal of this components. The study finding was consistent with the results reported by Hishe et al. (2017) and Hailu et al. (2012) for Middle Silluh valley, northern Ethiopia, and Goromti watershed western Ethiopia respectively. On the other hand, Challa et al. (2016), Husen et al. (2017), and Selassie et al. (2015) reported a statistically significantly lower bulk density in Tura plots than in Tuta plots. Soil pH showed slightly higher mean values in Tura plots. Relatively higher soil acidity in Tuta plots may be related with high rainfall, associated with leaching and removal of important soil nutrients. Amare et al. (2013) and Osman (2013) explained that high amount of rain water leaches soluble bases and consequently contributes to soil acidity. Similarly, longterm cropping, high rainfall, topographic steepness, and the application of inorganic fertilizer could probably increase soil acidity (Selassie et al. 2015). The analysis of variance result show that soil $\mathrm{pH}$ was not statistically significantly affected by conservation practices (Table 3 ). Similar results were reported by Challa et al. (2016) and Husen et al. (2017) in the central highland of Ethiopia. The effect of conservation measures on SOC, SOM, and TN has been significant in the watershed. This coincides with Challa et al. (2016), Hailu et al. (2012), Hishe et al. (2017), Selassie et al. (2015), and Sinore et al. (2018), who reported statistically significantly higher SOC in terraced landscapes. It could be mainly related with conservation structures and biomass accumulation (Selassie et al. 2015). Soils exposed for severe erosion has been more vulnerable to decomposition of SOC than slightly eroded soils (Abegaz et al. 2016). This implies that non-conserved soils are more vulnerable to erosion and most likely to have low SOC concentration as compared to conserved soils. As a result, supporting SWC structures by agro-forestry practice has been suggested for better carbon sequestration in the soil (Abegaz et al. 2016; Degefu et al. 2011). Similarly, supporting terracing with susbania and elephant grasses could result in high SOC and SOM due to high biomass return, which contributes to symbiotic fixation and soil erosion reduction (Sinore et al. 2018). However, we identified during on-site observation that as an agro-forestry and gully rehabilitation system, eucalyptus tree plantations were predominantly used to limit soil erosion and other related benefits in the study watershed. However, it was reported that the use of eucalyptus tree limits undergrowth and its contribution for SWC has been poor (Fikreyesus et al. 2011) and it is highly nutrient and water consuming species (Wolancho 2015). Hence, there is a need to recommend other better alternative tree plantations in the area. The variation is primarily explained by conservation effects on soil erosion, because soil bund reduces loss of fine soil particles and residues (Husen et al. 2017; Mengistu et al. 2016; Selassie et al. 2015; Sinore et al. 2018). This process further improves the concentration of SOM and SOC which consequently leads to increase TN in the soil. The result was consistent with Challa et al. (2016), Hailu et al. (2012), Husen et al. (2017), Selassie et al. (2015), and Sinore et al. (2018), who stated that conserved plots resulted in significantly higher TN content. On the other side, the result did not agree with the findings of Hishe et al. (2017) who reported statistically non-significant difference in plots following treatments. The available phosphorous content of the soil between conserved and non-conserved plots did not have consistent pattern with conservation measures. The application of diammonium phosphate (DAP) may be the reason for its indistinguishable availability in the soil. This result coincides with the result reported by Hishe et al. (2017) for Middle Silluh valley, Northern Ethiopia. Hailu et al. (2012) did not find a statistically significant difference between treated and non-treated fields. Our result was not in agreement with Mengistu et al. (2016) and Selassie et al. (2015) who observed insignificant but higher available phosphorous concentration in conserved soils. The concentration of av. $\mathrm{P}$ in the soil in kechi watershed was deficient. This could be explained by different factors; the medium acidity nature of the soil and soil erosion through runoff may contribute to its limited availability in the soil. The limited availability of phosphorous in the soil may limit the growth and productivity of plants in the area. Phosphorous in the soil is highly required by plants and may cause slow growth when its concentration is very low (Hishe et al. 2017). The CEC and exchangeable basis content of the soil in the watershed was rated as high. This might be due to the inherent characteristics of the soil because fine textured soils have more exchangeable basis (Osman 2013). Soils having high clay and SOM content have strong probability to hold positively charged ions and consequently hold high CEC concentration (Selassie et al. 2015; Sinore et al. 2018). Conservation measures caused a relatively higher CEC and cation exchange capacity in conserved soils than in non-conserved plots. but the difference did not show statistical significance. Different researchers reported that the effect of SWC measures showed non-significant difference in the CEC content of the soil (such as Hailu et al. 2012; 
Hishe et al. 2017). On the other hand, the findings of Challa et al. (2016), Mengistu et al. (2016), and Selassie et al. (2015) reported significantly higher CEC contents in conserved soil. The variation among research reports may be attributed to the level of effectiveness of SWC measures due to variations in conservation types, proper construction, and maintenance. Sinore et al. (2018) reported a significantly higher CEC and exchangeable bases in a soil treated with susbania and elephant grasses than in controlled soil. Supporting terracing with such plants/ grasses strengthens the bund, generates high biomass, and increases OM and better control of erosion, consequently increases $\mathrm{CEC}$ in the soil.

\section{The impact of watershed intervention in different land uses}

The impact of watershed intervention found to be different in grazing and cultivated land uses. This is indicated by a significant variation in $\mathrm{SOC}, \mathrm{SOM}, \mathrm{TN}$, exchangeable $\mathrm{Na}+$ and $\mathrm{Mg} 2+$ in conserved and non-conserved cultivated land uses and only exchangeable $\mathrm{Na}+$ in grazing land uses. The highest sand fraction was recorded from non-conserved cultivated land and lowest in conserved grazing land. Similarly, Hishe et al. (2017) reported greater sand content in non-terraced farm land. The effect of conservation measures caused greater mean variation of clay content in grazing land uses than in cultivated land uses. The highest (31.3\%) and lowest $(23.7 \%)$ silt content was observed in conserved and non-conserved grazing land uses, respectively (Table 4). This result did not agree with the findings of Hishe et al. (2017) who reported that lowest silt content was recorded in non-terraced cultivated land uses. A relatively lower bulk density, higher SOC, SOM, and total nitrogen were observed in conserved cultivated land than in grazing land uses as compared to their counterpart. Higher SOC concentration was observed in grazing land uses than in cultivated land uses. Abegaz et al. (2016) explained that higher concentration of SOC was observed in cultivated land which makes this land uses to loss SOM more quickly than grazing land uses. The effect of SWC measures has reduced the removal of soil particles, residues, and other organic matter. On the other hand, non-conserved soils are exposed to greater removal of these components that may lead to relatively better effectiveness of conservation measures in cultivated land uses. The analysis result showed that the effectiveness of SWC was better and significant (for some soil fertility indicators) in cultivated land than in grazing land. This might be related with high removal of fine nutrient-rich soil particles due to soil erosion in cultivated land (Belayneh et al. 2019) and conservation structures reduced soil loss in conserved plots. The key informant interview indicated that little or no attention was given for maintenance of conservation structures mainly in grazing land. This is due to communal ownership of most of the grazing land uses and waiting for any community mass-mobilization. On the other hand, the destruction of conservation structures was very high due to year-round open grazing. The result was supported by Wolancho (2015), who stated that controlling watershed intervention in communal grazing lands was poor and its effect was minimal.

\section{The correlation between soil properties}

The correlation matrix implies that most of the soil physical and chemical properties vary together. Soil $\mathrm{pH}$ had a positive significant relationship with SOM, TN CEC, exchangeable $\mathrm{Na}+, \mathrm{K}+$, and $\mathrm{Ca} 2+$. This indicated that many of the soil properties vary together with soil $\mathrm{pH}$ and it determines the availability of other physicochemical properties of the soil and vice versa. The presence of high organic matter, CEC, and basic cations improved the pH of the soil (Sinore et al. 2018). Moderately significant negative relationships were also observed between bulk density and TN, clay content, and basic cations except $\mathrm{Ca} 2+$. This could be due to the availability of high organic matter and fine soil particles in the soil (Hishe et al. 2017); Sinore et al. 2018). Principally, the availability of SOM, SOC, TN, CEC, and basic cations showed strong relationship. With respect to this, the implementation of watershed intervention improved most of these soil properties significantly (such as SOC, SOM, TN, and some cations) in this study and other studies (Challa et al. 2016; Hishe et al. 2017; Sinore et al. 2018; Mengistu et al. 2016; Selassie et al. 2015). Therefore, it gives an important lesson that the improvement in SOM, CEC, and clay content can also indirectly influence other properties and rehabilitates the soil to be healthier through its aggregate effect.

\section{Conclusion}

Watershed intervention has been an important means to reverse the degraded land and limit further damages to the land resources. They have been a tool for the communities to care for their local environment. This study evaluated the impact of watershed intervention in improving soil physicochemical properties in kechi micro watershed. In this regard, the study revealed that SWC resulted in improvement in soil nutrient content in kechi micro watershed. Soil organic matter, soil organic carbon, total nitrogen, and exchangeable $\mathrm{Na}+\operatorname{and} \mathrm{Mg} 2+$ showed significantly higher mean values in conserved plot as compared to non-conserved plots. Furthermore, the mean values of soil $\mathrm{pH}$, bulk density, clay content, caution exchange capacity, and exchangeable Ca2+ were better following conserved and non-conserved plots, even if the difference was not statistically significant. Our results also showed that the effectiveness of SWC measures was better in cultivated land than in grazing land. 
This could be mainly related with poor management and maintenance of conservation structures in grazing land, year-round open grazing with little attention for treatments. SWC practices are effective ways in minimizing soil erosion and improving soil fertility mainly in cultivated lands. However, in general, the issue of continuity (spatial and temporal), maintenance, and reconstruction of structures has been given little attention, which is among the main challenges for limited effect of SWC practices in the watershed.

As a result, regular community mobilization for conservation, assistance, maintenance, and reconstruction of demolished structures needs better attention from the concerned stakeholders, mainly the local government. Since conservation structures were constructed through community mass-mobilization in a campaign form, some individual farmers have been reluctant to retain and maintain structures for long. In addition, supporting SWC structures with grasses and trees is very important for strengthening their effectiveness in improving soil fertility and decrease soil erosion in the watershed.

\section{References}

Abbate E, Bruni P, Sagri M (2015) Geology of Ethiopia: a review and geomorphological perspectives. In: Billi P (ed) Landscapes and landforms of Ethiopia. Springer, Dordrecht, pp 33-64. https://doi.org/10.1007/978-94017-8026-1 2

Abegaz A, Winowiecki LA, Vagen T-G, Langan S, Smith JU (2016) Spatial and temporal dynamics of soil organic carbon in lands capes of the upper Blue Nile Basin of the Ethiopian highlands. Agric Ecosyst Environ 218:190-208. https://doi.org/10.1016/j.agee.2015.11.019

Adgo E, Teshome A, Mati B (2013) Impacts of long-term soil and water conservation on agricultural productivity: the case of

AnjeniAdimassu Z, Mekonnen K, Yirga C, Kessler A (2014) Effect of soil bunds on run-off, soil and nutrient losses, and crop yield in the central highlands of Ethiopia. Land Degrad Develop 25(6):554-564. https://doi.org/10.1002/ldr.2182

Amare T, Terefe A, Selassie YG, Yitaferu B, Wolfgramm B, Hurni H (2013) Soil properties and crop yields along the terraces and toposequece of Anjeni watershed, central highlands of Ethiopia. J Agric Sci 5(2):134-144. https://doi. org/10.5539/jas.v5n2p134

Bekele A, Aticho A, Kissi E (2018) Assessment of community based watershed management practices: emphasis on technical fitness of physical structures and its effect on soil properties in Lemo district, Southern Ethiopia. Environ Syst Res 7:20. https://doi.org/10.1186/s40068-018-0124-y

Belayneh M, Yirgu T, Tsegaye D (2019) Potential soil erosion estimation and area prioritization for better conservation planning in Gumara watershed using RUSLE and GIS techniques. Environ Syst Res 8:20. https://doi.org/10.1186/s4 0068-019-0149-x

Degefu T, Woldemeskel E, Frostegard A (2011) Multilocus sequence analyses reveal several unnamed Mesorhizobium genospecies nodulating Acacia species and Sesbania sesban trees in southern regions of Ethiopia. Syst Appl Microbiol 34:216-226. https://doi.org/1 0.1016/j.syapm.2010.09.006

Environment for Development (2010) Green accounting puts price on Ethiopian soil erosion and deforestation. Retrieved from http://efdinitiative.org/ourwork/policy-interactions/green-accounting-puts-price-ethiopiansoil-erosionand-deforestation

Fikreyesus S, Kebebew Z,Nebiyu A, Zeleke N, Bogale S (2011) Allelopathic effects of Eucalyptus camaldulensis Dehnh. on germination and growth of tomato. Am-Eurasian J Agric Environ Sci 11(5):600-608

Gemechu A (2016) Estimation of soil loss using revised universal soil loss equation and determinants of soil loss in Tiro Afeta and Dedo districts of Jimma zone, Oromiya National Regional State, Ethiopia. Trends Agri Econ 9(1-3):1-12. https://doi.org/10.3923/tae.2016.1.12

Hailu W, Moges A, Yimer F (2012) The effects of 'Fanya juu' soil conservation structure on selected soil physical \& chemical properties: the case of Goromti watershed, Western Ethiopia. Resour Environ 2(4):132-140. https://doi.org/1 0.5923/j.re.20120204.02

Haregeweyn N, Berhe A, Tsunekawa A, Tsubo M, Meshesha DT (2012) Integrated watershed management as an effective approach to curb land degradation: a case study of Enabered watershed, northern Ethiopia. Environ Manag 50(6):1219-1233. https://doi.org/10.1007/s00267- 012-9952-0

Hishe S, Lyimo J, Bewket W (2017) Soil and water conservation effects on soil properties in the Middle Silluh Valley, northern Ethiopia. Int Soil Water Conserv Res 5:231-240. https://doi.org/10.1016/j.iswcr.2017.06.005

Hurni H (1993) Land degradation, famine and resources scenarios in Ethiopia. In: Pimental D (ed) World soil erosion and conservation. Cambridge University Press, Cambridge

Hurni H, Debele B, Zeleke G (2015) Saving Ethiopia's soils. In: Ehrensperger A, Ott C, Wiesmann U (eds) Eastern and southern Africa partnership Programme: highlights from 15 years of joint action for sustainable development. Centre for Development and Environment, University of Bern with Bern Open Publishing, Bern, pp 27-30. https://doi.org/10.7892/ boris. 